\title{
Emergence of Blue Sky Over Delhi Due to Coronavirus Disease (COVID-19) Lockdown Implications
}

\author{
Garima Kotnala $^{1,2} \cdot$ T. K. Mandal ${ }^{1,2} \cdot$ S. K. Sharma ${ }^{1,2} \cdot$ R. K. Kotnala ${ }^{1,2,3}$
}

Received: 12 April 2020 / Revised: 29 April 2020 / Accepted: 8 May 2020 / Published online: 25 May 2020

(c) Institute of Earth Environment, Chinese Academy Sciences 2020

\begin{abstract}
Due to coronavirus pandemic (COVID-19) prevailing in more than 210 countries, out of them only few have promulgated lockdown and on March 24, 2020 India also implemented lockdown for 21 days to prevent the community spread of virus among people. Since then, lockdown heavily restricts travel movements of flights, rail, intercity bus services besides industrial activity halt throughout the country. The significant improvement in the air quality of Delhi region was observed due to strict implementation of lockdown. During the lockdown period, improvement in ambient air quality helped us in circumventing the coronavirus community spread. The preliminary results showing the decrease in horizontal advection of pollutants has given an opportunity to understand the background concentrations of air pollutants over Delhi. To analyse this peculiar situation, we have assessed the pollutants datasets collected by twelve different online ambient air quality monitoring stations (AQMS) of Central Pollution Control Board (CPCB), New Delhi, India and observed a colossal improvement in the ambient air quality. The analysis of data confirms the sharp decline in concentrations (nearly 200\%) of $\mathrm{PM}_{2.5}$ and $\mathrm{PM}_{10}$. The concentration of nitrous oxides $\left(\mathrm{NO}_{x}\right.$ ), recorded its maximum ( $342 \mathrm{ppb}$ ) on 12 January 2020 in CRRI-Mathura Road, Delhi with the lowest value as $24 \mathrm{ppb}$ on 30 March 2020 (reduced to nearly 14 times of the peak value). In the triad of this infectious disease, the role of environment is not linked better however, the ground reality cannot be ignored due to environment around us receives, maintains, protects and transports the aetiological agents to host prevailing in polluted environment which makes our lungs more susceptible to viral attacks. Therefore, a cleaner environment would prove to be an effective measure to halt and reduce the transmission of viral infections.
\end{abstract}

Keywords Pandemic $\cdot$ WRI-CAIT $\cdot$ Particulate matter $\cdot$ Air quality

\section{Introduction}

The Delhi air flux is the most pernicious consequences of indiscriminate industrialisation and urbanisation. The WHO (2020) report stunned with the 4.2 million premature death tolls annually due to air pollution and it has estimated that nearly $90 \%$ urban inhabitants live in air pollution that exceeds WHO guidelines. It has been observed that the people living in the areas of beyond safer levels of air to

S. K. Sharma

sudhir.npl@nic.in; sudhircsir@gmail.com

1 Environmental Sciences and Biomedical Metrology Division, CSIR-National Physical Laboratory, Dr. K S Krishnan Road, New Delhi 110 012, India

2 Academy of Scientific and Innovative Research (AcSIR), Ghaziabad 201 002, India

3 Department of Atomic Energy, Mumbai, India breath are more vulnerable to Novel Coronavirus Disease COVID-19. It was reported that the higher levels of air pollution compromise individual's lung function that results into more vulnerability to virus infections (Wang et al. 2020; Kanawade et al. 2019; Nahid et al. 2019). In early December 2019, the capital Hubei province in central China, city Wuhan diagnosed a patient with an unusual pneumonia of unknown cause (Cadotte et al. 2019). By 31 December 2019 in Beijing, the WHO notified with an array of pneumonia patients from Wuhan itself. Researchers at "Wuhan Institute of Virology" after a rigorous study identified a potential aetiology "Novel Corona Virus-19 with an incubation period expected within 6.4 days (Backer et al. 2020). In the triad of the infectious diseases, the role of environment is ambiguous. However, it is well known that air receives aetiological agents onto aerosols/particulate matter as host in prevailing polluted environment which are inhaled into our lungs through respiratory tract; hence, we are more susceptible to 
viral attacks. Therefore, a cleaner environment would prove to be a measure to halt and reduce the transmission of viral infections, such as COVID-19, SARS and MERS (Tesini 2020).

It is well known that air pollutants present in the atmosphere in different concentrations disturb the dynamic equilibrium in the atmosphere and thereby affect our health and environment (De Anil 2019). In general, five primary pollutants are opted to determine the air quality namely carbon monoxide $(\mathrm{CO})$, nitrogen oxides $\left(\mathrm{NO}_{x}\right)$, hydrocarbons ( $\mathrm{HCs})$, sulphur oxides $\left(\mathrm{SO}_{2}\right)$ and particulate matter (PM). However, the evaluation of the pollutants and the sources in terms of tonnage does not give the correct picture since even a minor pollutant can be much more dangerous than a major pollutant for our health. Thus, particulate pollutants are the most dangerous among the primary pollutants. PM falls in the category of carcinogen (Raaschou and Andersen 2013) and elevates the risk of heart attacks (Cesaroni et al. 2014). The prolonged exposure to $\mathrm{NO}_{2}$ and $\mathrm{SO}_{2}$ can damage lung tissues which could be a big factor in the emergence of asthma and lung cancer (Greenberg et al. 2016; Khaniabadi et al. 2017). A study on the Severe Acute Respiratory Syndrome (SARS) Coronavirus outbreak in China in the year 2003 found that infected people from highly polluted areas were twice as likely to die from the virus as those from the cleaner environment. Studies also found that as the pollution levels spiked from $4 \%$ in less polluted region to $7.5 \%$ inmoderately polluted region up to $9 \%$ in highly polluted locations, the SARS death rate increased sharply (Tesini 2020). Moreover, the Middle East Respiratory Syndrome (MERS) corona virus outbreak in Saudi Arabia from the year 2012 indicated that tobacco smokers were more vulnerable to die from the virus. Hence, indications from the previous virus outbreaks coupled with the statistical analysis imply at a link between air pollution and COVID-19 that cannot be ignored.

Lockdown is an emergency protocol from the Government to shut down most of the offices, industries, private companies and not to allow people to move from a given area. Due to coronavirus pandemic prevailing in more than 200 countries and some of them have promulgated lockdown (Bukhari and Jameel 2020). On March 24, 2020 India also imposed lockdown for 21 days to prevent the community spread of virus among people. Since then, lockdown allows only movement of essential supplies, grocery items, pharmacies and banks to continue to serve the people. However, heavily restricted travel restrictions have been imposed on transport movements of flights, rail and intercity bus services have been suspended throughout the country (India Weather Report 2020, https://www.weather.com/en-IN/india /pollution/news/2020-03-18-covid-19-pollution-smokingvulnerable-novel-coronavirus-disease). Within two days of lockdown, a significant improvement in the air quality was observed, which prompted us to analyse the air quality level as one of the best model on Delhi environment. For last few months beginning from November 2019, Delhi air quality has been recorded in unhealthy zone, most of the time, except during the lockdown period when it explicitly confirms the better air quality. India has been struggling hard for few years to mitigate environment pollution by funding high value projects, but no significant solution could be achieved in this direction. A Boon for masses to breathe healthy air has been realised only after imposing lockdown to circumvent the community spread of corona virus. Due to this, the air quality improved to healthy from worse quality and it can be directly correlated to the functioning of bare minimum industries, vehicular and air traffic movement which resulted into a very low emissions of pollutants in the air. Restricted transport, human activities, commercial and industrial activities during COVID-19 pandemic has revealed direct impact on air quality of Delhi region (CPCB 2020). The COVID-19 outbreak emergency measures to circumvent the transmission rate of virus from one person to other person but in turn, it also resulted in unprecedented dramatic drop in pollutants emissions. The novel coronavirus (COVID-19) has infected over more than one million people in more than 200 counties, territories and two international conveyances across the world, a scourge confronting all of humanity, impacting economies, lifestyles, trade and commerce by inducing turbulence on global economy and attenuating the trade flow growth. The situation has now been aggravated by the demand, supply and liquidity shocks that COVID-19 has inflicted. Once the pandemic is controlled, the shape and speed of the recovery in the USA and China would be the key factors in determining the traction and nature of global economic recovery (Report No. 1, 2020).

The United Nations Conference on Trade and Development (UNCTAD) in its latest report "The COVID-19-Shock to developing countries" has predicted that major economies least exposed to recession would be India and China (UN report 2020). In the present study, we report the ambient air quality (trace gases and particulate matter) of megacity of Delhi during lockdown period in comparison to before the lockdown period measured at different ambient air quality monitoring stations (AQMS) of CPCB across the Delhi (www.cpcb.nic.in).

\section{Methodology}

\subsection{Description of Sites and Data Collection}

Delhi, the capital of India, is situated $\left(28.61^{\circ} \mathrm{N}, 77.23^{\circ}\right.$ E) in the northern part of the India. It is located between the mountain ranges of the Great Himalayas and Aravallis. The area of Delhi is surrounded by four different climatic zones [Himalayas in the north, central hot plains in the 
south, the Thar desert in the west and the Indo Gangetic plain (IGP) in the east], which influence its semi-arid climate and considered as one of the most polluted megacities in the world. In general, the meteorology of Delhi is divided into four distinct seasons: winter (January-February), summer (March-June), monsoon (July-September) and post-monsoon (October-December). The details of pollutants datasets collected from different AQMS (Fig. 1) are discussed below:

The pollutants data were collected from online AQMS of CPCB, New Delhi, India (available on CPCB website: cpcb.nic.in for users). The pollutants $\left(\mathrm{PM}_{2.5}, \mathrm{PM}_{10}\right.$, $\mathrm{CO}$, $\mathrm{NO}_{x}, \mathrm{NH}_{3}, \mathrm{NO}, \mathrm{NO}_{2}$ and $\mathrm{SO}_{2}$ ) datasets (for two different periods) of 12 AQMS (Fig. 1) of Delhi were downloaded from CPCB website and analysed to assess the ambient air quality of Delhi before and during the lockdown period.
The details of datasets used in the study are summarised in Table 1.

The details of, methodology and instruments used by online AQMS of CPCB, New Delhi, India are summarised in Table 2.

The Site at Anand Vihar records the highest $\mathrm{NO}_{x}$ concentration (Fig. 2) which might be due to Anand Vihar being one of the busiest intercity bus terminal of India clogged with extremly heavy slow traffic of buses, trucks and cars. The bus engines are kept ideal for 15-20 min prior to arrival and departures emanating the large quantity of $\mathrm{NO}_{x}$, ultimately leading to the spikes. It is reduced from 121.5 to $44.1 \mathrm{ppb}$ on Janta Curfew Day (22 March 2020) that finally settles at a surprising value of $26.1 \mathrm{ppb}$ on 31 March 2020 .

The Site at ITO records the highest peak at $124.5 \mu \mathrm{g} / \mathrm{m}^{3}$ for $\mathrm{PM}_{2.5}$ concentration on 20 January 2020, declining down to $82.9 \mu \mathrm{g} / \mathrm{m}^{3}$ (Fig. 2) on Janta Curfew Day (22 March 2020)

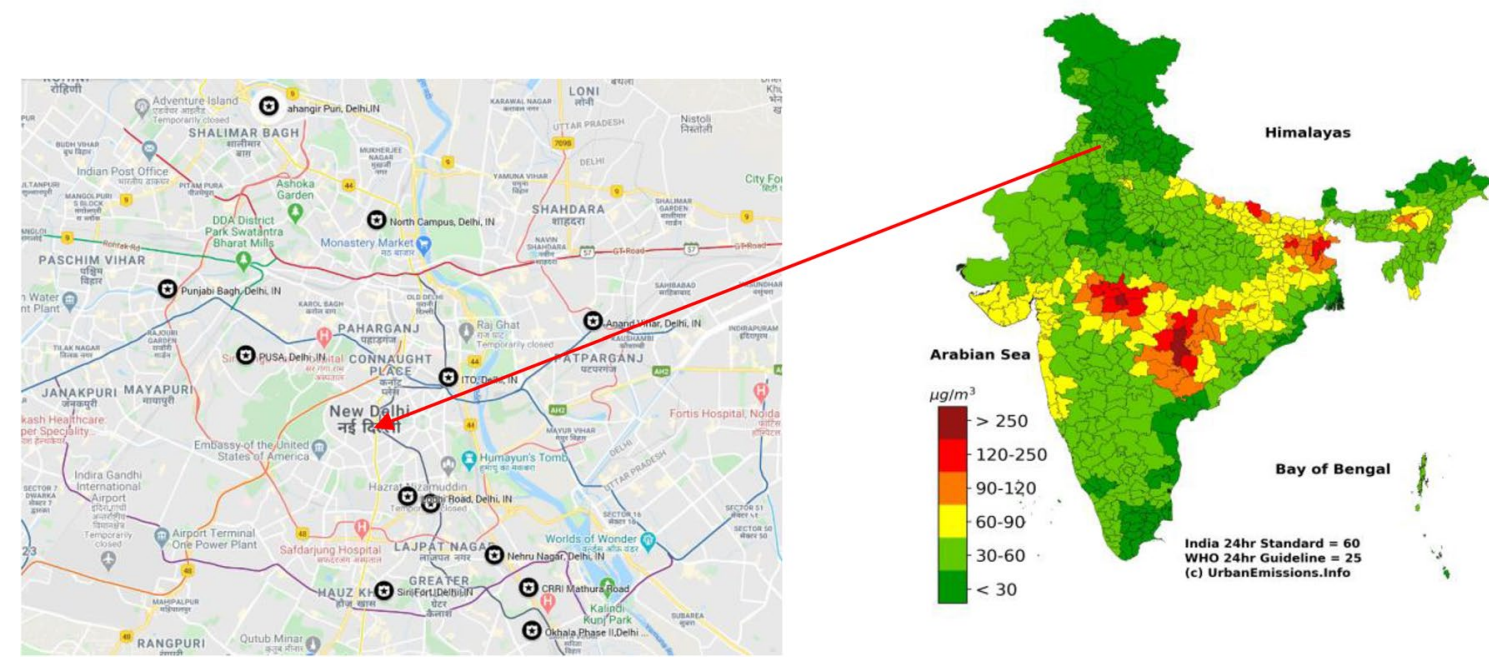

Fig. 1 Left: marked 12 AQMS of Delhi (data collected during the study period) (Souce: Google map); right: 24 h average PM concentration collected from India Air Quality Information (Urban emissions.info)

Table 1 The data for Delhi state were taken from CPCB website on 31 March 2020

\begin{tabular}{|c|c|c|}
\hline Datasets & Locations & Parameters assessed \\
\hline $\begin{array}{l}\text { 1. During global COVID-19 } \\
\text { outbreak (1 January 2020-31 } \\
\text { March 2020) }\end{array}$ & $\begin{array}{l}\text { North Campus (mixed area) } \\
\text { Pusa (residential cum industrial) } \\
\text { Lodi Road (residential area) } \\
\text { CRRI-Mathura Road (residential + commercial) }\end{array}$ & $\begin{array}{l}\mathrm{PM}_{10}\left(\mu \mathrm{g} / \mathrm{m}^{3}\right) \\
\mathrm{PM}_{2.5}\left(\mu \mathrm{g} / \mathrm{m}^{3}\right) \\
\mathrm{NO}_{x}(\mathrm{ppb}) \\
\mathrm{CO}\left(\mathrm{mg} / \mathrm{m}^{3}\right)\end{array}$ \\
\hline $\begin{array}{l}\text { 2. Pre-lockdown and Post-lock- } \\
\text { down period data (15 March } \\
\text { 2020-31 March 2020) }\end{array}$ & $\begin{array}{l}\text { Anand Vihar (commercial cum residential) } \\
\text { ITO (commercial) } \\
\text { Jahangir Puri (mixed area) } \\
\text { Jawaharlal Nehru Stadium (JLN) (commercial cum } \\
\text { residential area) } \\
\text { Nehru Nagar (mixed area) } \\
\text { Okhla Phase } 2 \text { (industrial cum commercial) } \\
\text { Punjabi Bagh (residential) } \\
\text { Siri fort (residential cum } \\
\text { commercial) }\end{array}$ & $\begin{array}{l}\mathrm{PM}_{2.5}\left(\mu \mathrm{g} / \mathrm{m}^{3}\right) \\
\mathrm{NH}_{3}\left(\mu \mathrm{g} / \mathrm{m}^{3}\right) \\
\mathrm{NO}\left(\mu \mathrm{g} / \mathrm{m}^{3}\right) \\
\mathrm{NO}_{2}\left(\mu \mathrm{g} / \mathrm{m}^{3}\right) \\
\mathrm{NO}_{x}(\mathrm{ppb}) \\
\mathrm{SO}_{2}\left(\mu \mathrm{g} / \mathrm{m}^{3}\right) \\
\mathrm{CO}\left(\mathrm{mg} / \mathrm{m}^{3}\right)\end{array}$ \\
\hline
\end{tabular}


Table 2 Methodology used in measurement of pollutants by AQMS, CPCB, New Delhi, India

\begin{tabular}{llll}
\hline S. no. & Pollutants & Duration (h) & Principle/methods \\
\hline 1 & $\mathrm{PM}_{2.5}, \mathrm{PM}_{10}$ & 24 & TOEM, beta attenuation \\
2 & Nitrogen dioxide $-\mathrm{NO}_{2}\left(\mu \mathrm{g} / \mathrm{m}^{3}\right)$ & 24 & Chemiluminescence \\
3 & Sulphur dioxide- $\mathrm{SO}_{2}\left(\mu \mathrm{g} / \mathrm{m}^{3}\right)$ & 24 & UV fluorescence \\
4 & Carbon monoxide- $\mathrm{CO}\left(\mathrm{mg} / \mathrm{m}^{3}\right)$ & 24 & Non-dispersive infra- \\
& & & red (NDIR) spectros- \\
& & 24 & copy \\
5 & Ammonia- $\mathrm{NH}_{3}\left(\mu \mathrm{g} / \mathrm{m}^{3}\right)$ & & Chemiluminescence \\
\hline
\end{tabular}

and then on 30 March 2020 the $\mathrm{PM}_{2.5}$ concentration settles to $46 \mu \mathrm{g} / \mathrm{m}^{3}$. The ITO being a commercial area mostly overcrowded with vehicles and connects with major heavy traffic of Delhi ring road, the possible large emissions could be emanating from a 10-15 min halt of vehicles at traffic signal stoppage while, car engine ignition remain switched on.

Similar, interesting trends can be seen for site at Siri Fort (being a residential cum commercial area; it is surrounded by Delhi University colleges and a fast moving heavy traffic during peak hours.), Site at Jahangir Puri (a mixed site) which is located on NH-9 that further merges with $\mathrm{NH}-44$ nearly in $400 \mathrm{~m}$. Also this site shows high concentration of aerosols as it has a huge JJ-Colony cluster adjoining, besides the city waste disposal dumpyard, site at Jawahar Lal Nehru Stadium (residential plus commercial site), emissions could be coming from huge number of vehicles coming just next to the stadium for one of the biggest official complex: CGO Complex. Additionally, there being defence offices too. Lots of defence heavy duty vehicles come to the complex site at Nehru Nagar (site being on ring road is densely populated too with a high volume of traffic throughout the day. Moreover, this site is just close by to the Delhi-Noida biggest cross-section; thereby, giving the high concentration of emissions from vehicular exhausts), site at Okhla Phase-2 (This site is commercial cum industrial with crowded residencies nearby like Govind Puri along with a huge number of service stations for cars are also located in Okhla Phase-2 site.) and site at Punjabi Bagh (a densely populated residential site; therefore, heavy concentartion of traffic could be a reason for spiked emission peaks).

\section{Results and Discussion}

The capital city Delhi of India has been also impacted by COVID-19 pandemic by the mid of February 2020, it prompted us to analyse Delhi as one of the best model to assess the drop in air pollution level trend and background concentration of air pollutants over Delhi during lockdown period. To do so, we examined the CPCB data for consecutive 12 locations across Delhi regions. It was planned to consider database for $24 \mathrm{~h}$ of each day from 1 January
2020 to 31 March 2020. The data were retrieved for different parameters and it has been plotted to understand air quality trend which depicts typically, spiked concentration of PM in pre-lockdown period and abrupt decline in postlockdown period plot. The analysis presented in this paper reveals a direct comparison between the lockdown condition of corona virus and its direct remarkable impact on local environmental conditions. The experimental data pattern has been depicted which shows the significant drop in the PM and trace gases $\left(\mathrm{NH}_{3}, \mathrm{SO}_{2}, \mathrm{NO}, \mathrm{NO}_{2}, \mathrm{NO}_{x}\right.$ and $\left.\mathrm{CO}\right)$ concentrations in the respective plotted (Fig. 1) for eight locations throughout in Delhi (data of other four locations are not available). Although reports from multiple metropolitan areas around the world have also highlighted the substantial fall in the Urban pollution levels too (www.npr.org, https ://www.npr.org/sections/goatsandsoda/2020/03/04/81101 9032/why-chinas-air-hasbeen-cleaner-during-the-coron avirus-outbreak). According to the World Resources Institute (WRI)-CAIT, Country Greenhouse Gas Emissions data, India's transportation sector contribution is increasing every year from 191.3 $\mathrm{Mt} \mathrm{CO}_{2}$ (metric tons of carbon dioxide equivalent) in the year 2010 to $265.3 \mathrm{Mt} \mathrm{CO}_{2}$ (Wricait-country dataset,https://www.datasets.wri.org/dataset/ cait-countrym.economictimes.com/news/politics-and-natio n/lockdown-clears-up-indiasair/articleshow/74942627.cms) in the year 2016; which is immensely dropped during this corona virus outbreak. Indications from the previous outbreaks; coupled with statistical observations outlined amid the ongoing pandemic so far, hint at a strong link between air pollution and COVID-19 that cannot be ignored. The main air pollutants data have been reported in this work which includes: $\mathrm{PM}_{2.5}, \mathrm{PM}_{10}, \mathrm{NO}, \mathrm{NO}_{2}, \mathrm{NO}_{x}, \mathrm{SO}_{2}, \mathrm{CO}, \mathrm{NH}_{3}$, with following observations.

\subsection{Variation in $\mathrm{PM}_{10}$}

Indicates $\mathrm{PM}_{10}$ concentrations for four locations namely North campus, Pusa, Lodhi Road and CRRI-Mathura Road across Delhi during 1 January 2020 till 31 March 2020 on $24 \mathrm{~h}$ based sampling. Figure 4 exhibits the highest concentration of $\mathrm{PM}_{10}$ at $542 \mu \mathrm{g} / \mathrm{m}^{3}$ in CRRI-Mathura Road on 1 January 2020; reducing considerably to $396.5 \mu \mathrm{g} / \mathrm{m}^{3}$ on 


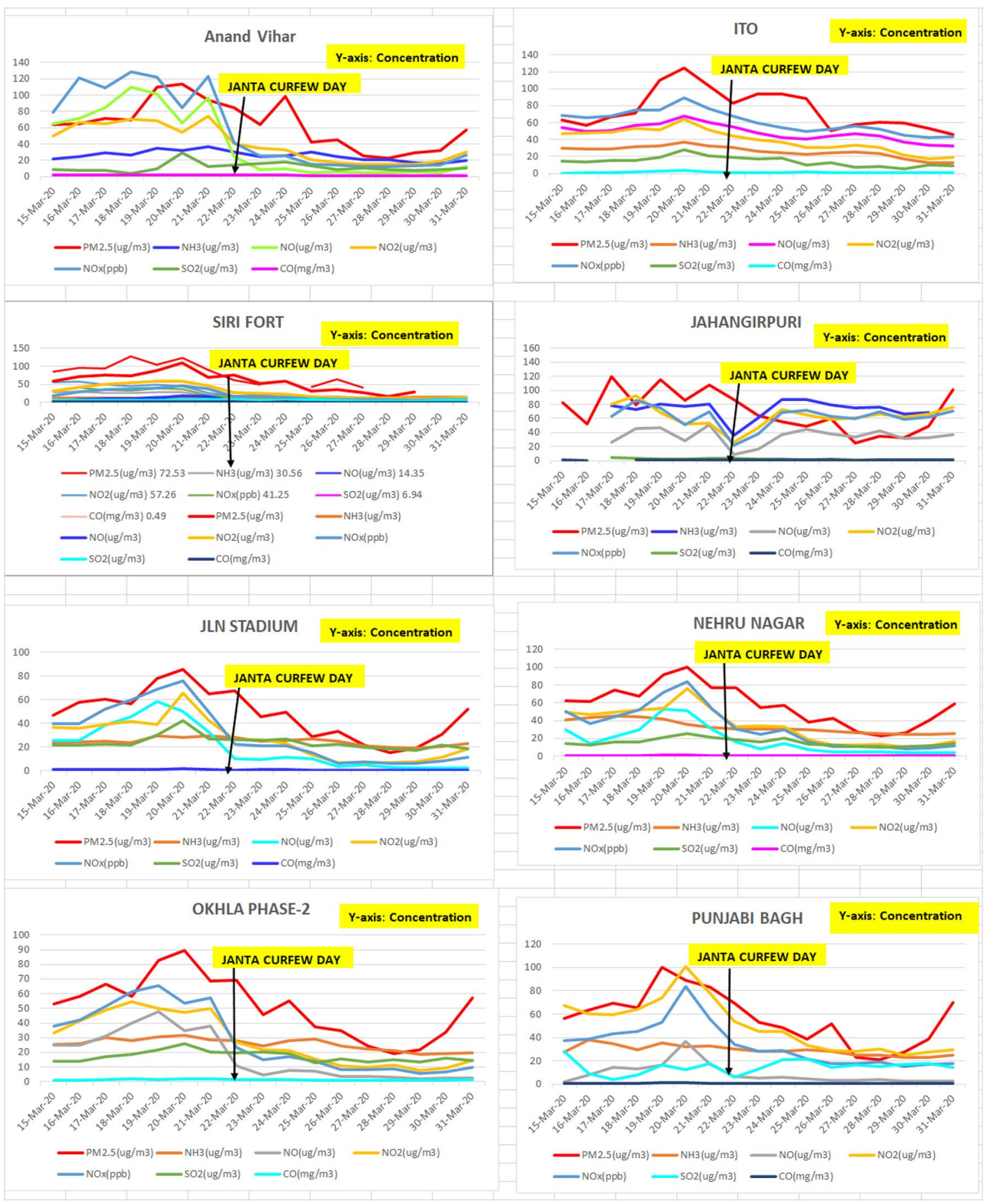

Fig. 2 Representation of the seven parameters of air pollutants during COVID-19 lockdown (eight locations across Delhi region)

11 February 2020, which further decreased to $55 \mu \mathrm{g} / \mathrm{m}^{3}$ on 29 March 2020 (Fig. 3). During the COVID-19 outbreak lockdown period for the same CRRI site that accounts for nearly $89 \%$ decline in the $\mathrm{PM}_{10}$ concentration. The IMD site at CRRI Mathura Road is just next to the major crosssection on National Highway-19 (NH-19); therefore; the site being on national highway with the fast-moving heavy traffic; thereby, depicting spiked $\mathrm{PM}_{10}$ concentration. Since the COVID-19 outbreak, Government implemented lockdown to avoid the virus transmission to masses and the logarithmic decay in $\mathrm{PM}_{10}$ concentration can be seen over this period in Fig. 4. 


\section{PM10 CONCENTRATION $\left(\mu \mathrm{g} / \mathrm{m}^{3}\right)$}

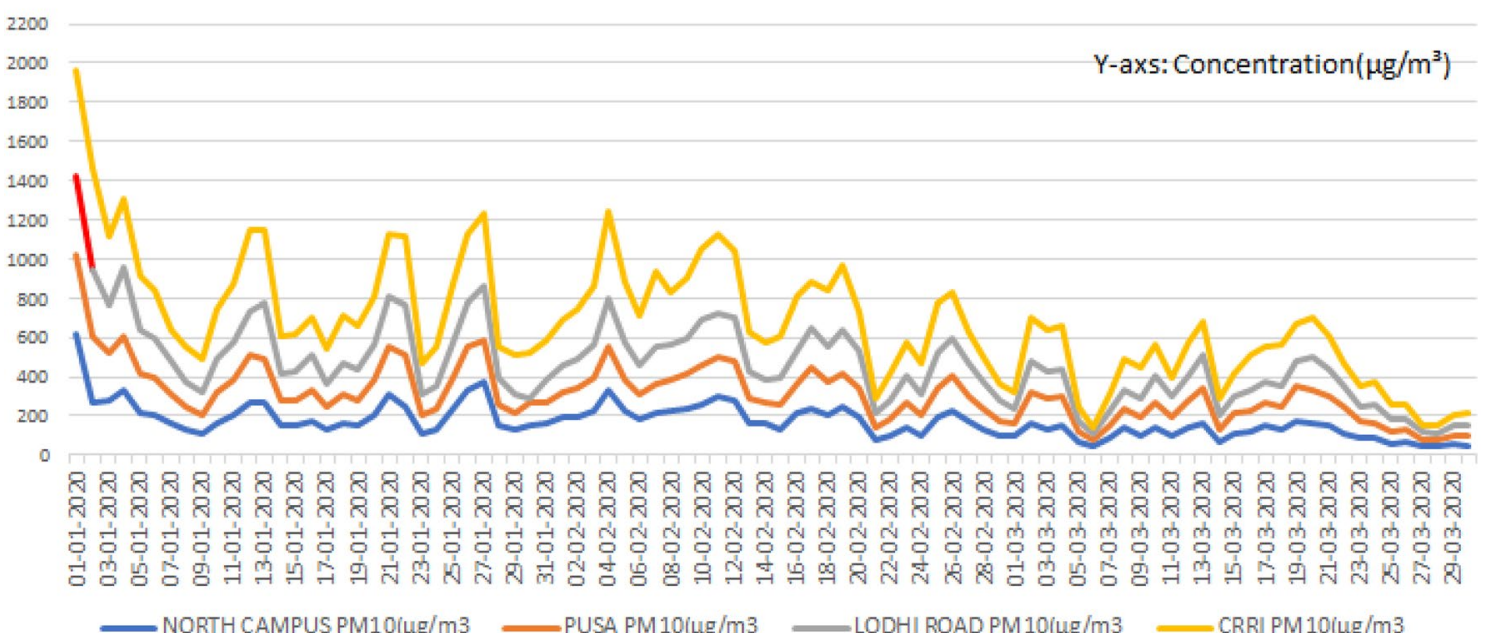

Fig. $3 \mathrm{PM}_{10}$ concentration trend before and during COVID-19 lockdown period

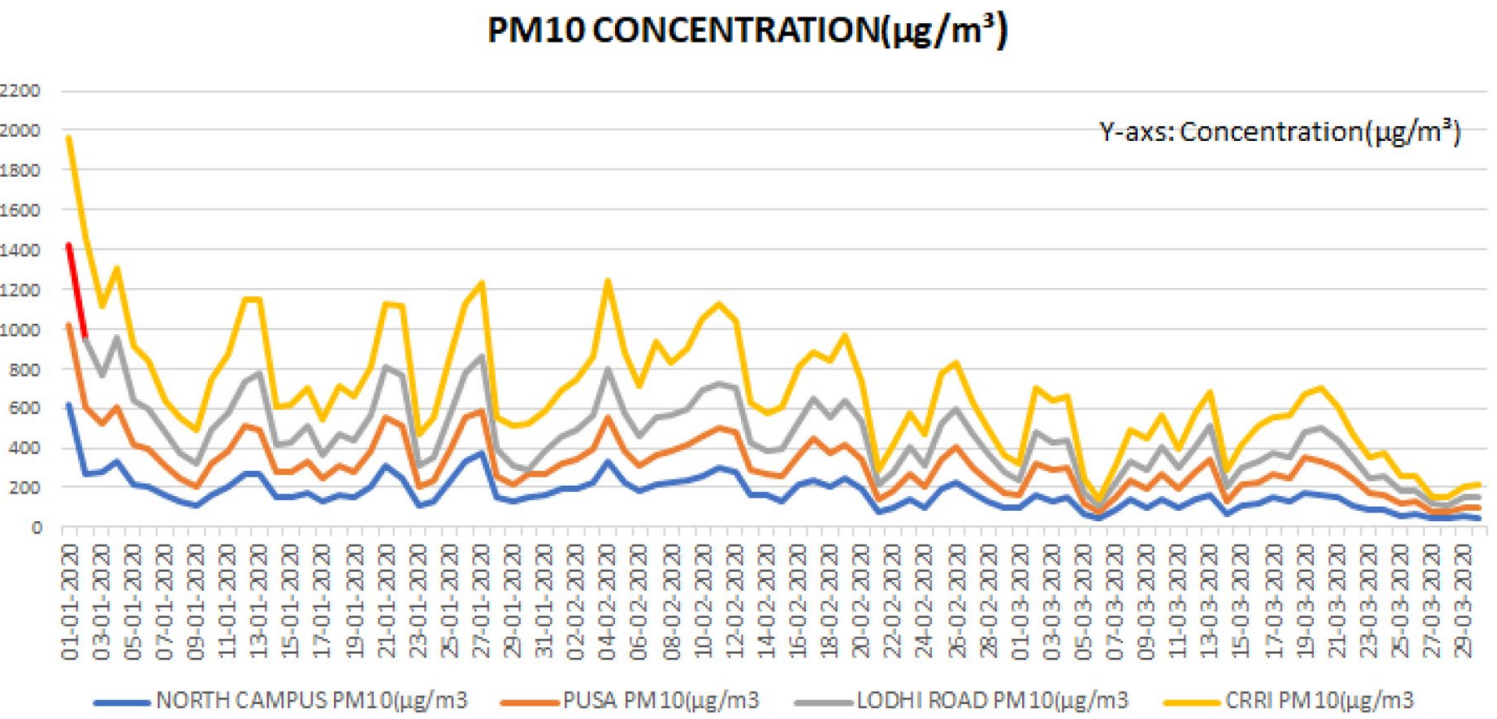

Fig. 4 Decrease in trend in $\mathrm{PM}_{2.5}$ concentration during COVID-19 lockdown period

\subsection{Variation in $\mathrm{PM}_{2.5}$}

\subsubsection{During 1 January 2020-31 March 2020}

A substantial decrease in $\mathrm{PM}_{2.5}$ concentration is explicit in Fig. 4 over four regions in Delhi during 1 January 2020-31 March 2020 on 24-h based sampling with a trend of the highest concentrations for North campus (Delhi University) at $424 \mu \mathrm{g} / \mathrm{m}^{3}$ on 1 January 2020 (Fig. 4) to moderate value $171 \mu \mathrm{g} / \mathrm{m}^{3}$ on 12 February 2020 and episodic concentration marks the lowest $20 \mu \mathrm{g} / \mathrm{m}^{3}$ on 30 March 2020, that depicts a significant drop of 95 in the $\mathrm{PM}_{2.5}$ concentration that is quite evident. Spiked $\mathrm{PM}_{2.5}$ concentrations at North campus (mixed area an IMD site) could be due to the overcrowded Delhi University campus with heavy traffic during peak days of the classes and time. Since Delhi is under the lockdown period, all colleges and workplaces are shutdown; hence, one may visualise a drastic decrease in $\mathrm{PM}_{2.5}$ concentration in Fig. 5.

\subsubsection{During lockdown period, 15 March 2020-31 March 2020}

$\mathrm{PM}_{2.5}$ concentration for pre-lockdown and post-lockdown period have been recorded in Fig. 6 over nine locations of Delhi with a peak at Jahangir Puri as $119 \mu \mathrm{g} / \mathrm{m}^{3}$ on 


\section{CO CONCENTRATION $\left(\mathrm{mg} / \mathrm{m}^{3}\right)$}

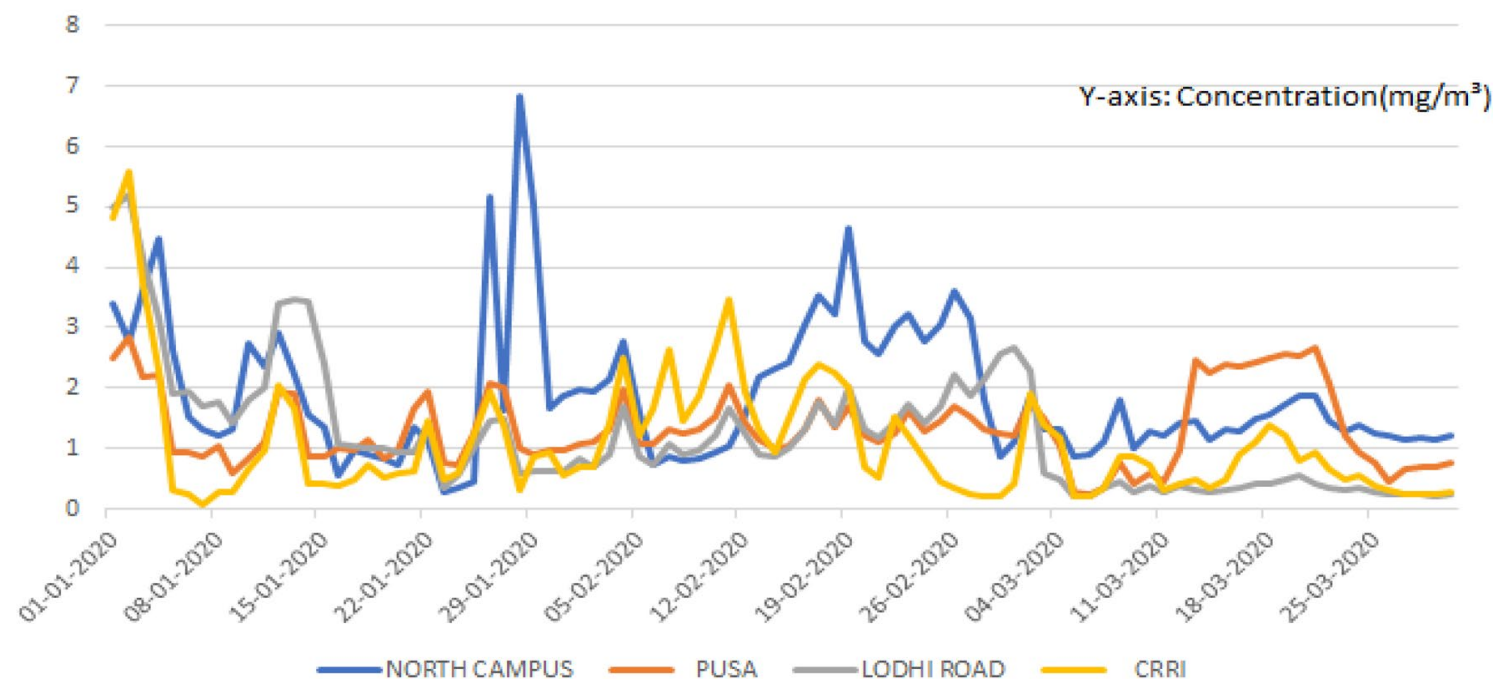

Fig. 5 CO concentration trend during COVID-19 lockdown period

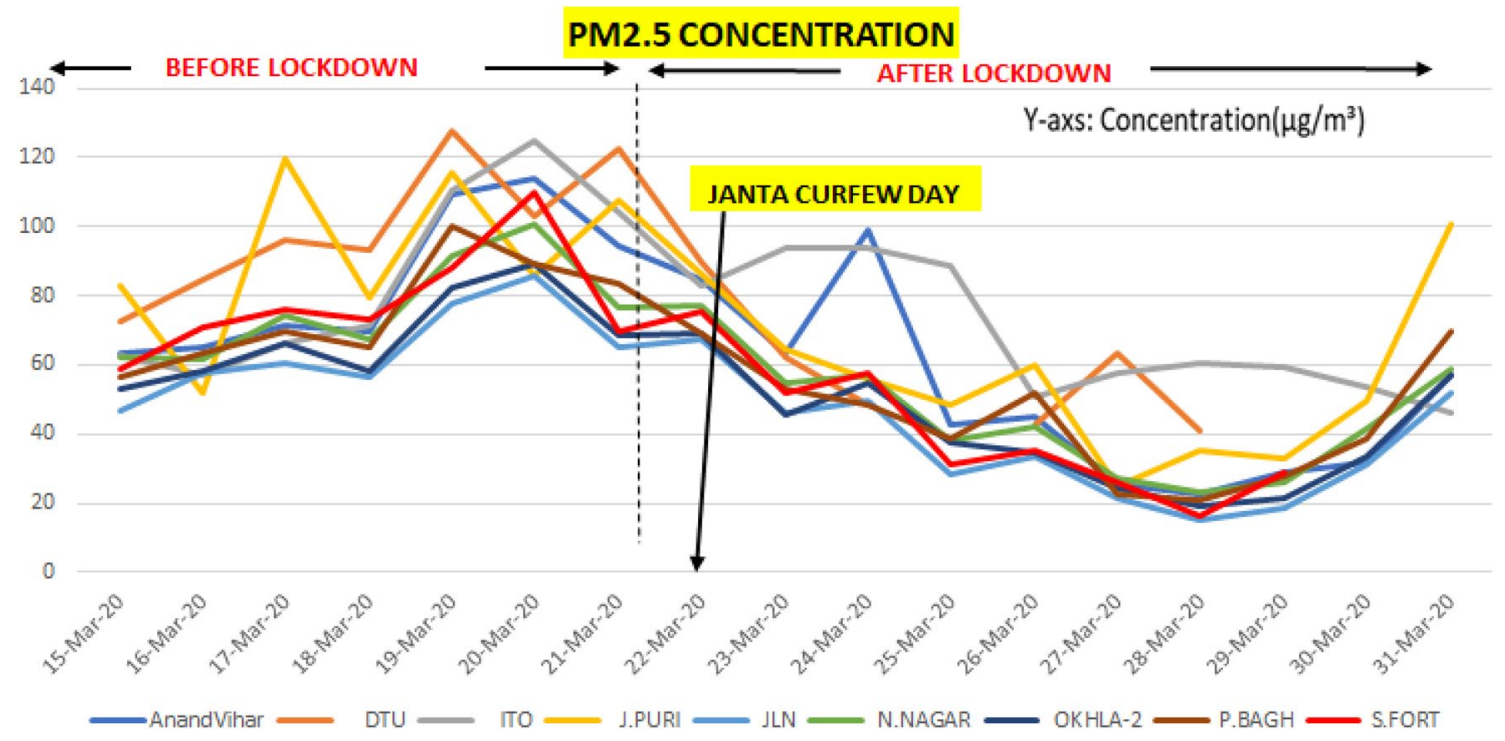

Fig. $6 \mathrm{PM}_{2.5}$ concentration during pre-lockdown and post-lockdown periods in Delhi

17 March 2020 (a week before lockdown) and the concentration was recorded moderate as $86 \mu \mathrm{g} / \mathrm{m}^{3}$ on Janta Curfew Day: 22 March 2020 with the lowest values at $33 \mu \mathrm{g} / \mathrm{m}^{3}$. On 29 March 2020 (during active lockdown period) at Jahangir Puri site (Fig. 6). Jahangir Puri being a mixed area observes heavy load vehicles with dense traffic throughout the day (being on National Highway 44), this site is also located adjacent to one of the biggest city dump yard and JJ Slum Area (where some portions of dump yard still continuing biomass burning too) colony nearby leading to higher side of $\mathrm{PM}_{2.5}$ concentrations before lockdown period, which further declines just post-curfew day.

\subsection{Variation in CO}

The CO concentration measured in $\mathrm{mg} / \mathrm{m}^{3}$ noticed significant rise for north campus site at $6.8 \mathrm{mg} / \mathrm{m}^{3}$ on 28 January 2020 , which further dropped at $4.6 \mathrm{mg} / \mathrm{m}^{3}$ on 19 February 2020 and then after witnessed the decline in CO concentration at $1.2 \mathrm{mg} / \mathrm{m}^{3}$ on 30 March 2020 as shown in (Fig. 5) 
which is nearly $82 \%$ drop in the $\mathrm{CO}$ concentration during the COVID-19 lockdown period. The $\mathrm{CO}$ declining trend may be due to North campus activity being a university area with narrow roads having multiple turns at shorter distances and more traffic light stoppages. Therefore, it results into vehicle's average speed limits to $10-20 \mathrm{~km} / \mathrm{h}$ and idling time of engines is also high that results into incomplete combustion from vehicular exhausts. Such situation leads to significant elevated levels of $\mathrm{CO}$ concentration. Thus, $\mathrm{CO}$ concentration in this region during COVID-19 lockdown is reduced.

\subsection{Variation in $\mathrm{NO}_{x}$}

The $\mathrm{NO}_{x}$ concentration measured in $\mu \mathrm{g} / \mathrm{m}^{3}$ observes a substantial increase in CRRI-Mathura Road site at $342 \mu \mathrm{g} / \mathrm{m}^{3}$ on 12 January 2020 as seen in Fig. 7. The probable source of $\mathrm{NO}_{x}$ due to heavy traffic site with a major Delhi-Noida cross-section adjacent to the monitoring station. Also, the heavy-duty vehicles (trucks, tempos, buses) are prominently using this route towards Badarpur-Faridabad road, possibly emanating $\mathrm{NO}_{x}$ concentration. Therefore, the appreciable fall in the $\mathrm{NO}_{x}$ concentration during the lockdown period at CRRI-Mathura road site to be $259.4 \mu \mathrm{g} / \mathrm{m}^{3}$ on 11 February 2020 that finally dropped at $24 \mu \mathrm{g} / \mathrm{m}^{3}$ on 30 March 2020 . The percentage decline in $\mathrm{NO}_{x}$ concentration is around $92 \%$ during the Corona pandemic.

\subsection{Variation in $\mathrm{NH}_{3}$}

Figure 8 shows the episodic trend of ammonia $\left(\mathrm{NH}_{3}\right)$ concentration during pre-lockdown and post-lockdown period with an interesting stand-alone peak for Jahangir Puri region at $120.9 \mu \mathrm{g} / \mathrm{m}^{3}$ on 15 March 2020 (pre-lockdown period), $86.8 \mu \mathrm{g} / \mathrm{m}^{3}$ on 24 March 2020 and the significant decrease in the ammonia concentration at $20 \mu \mathrm{g} / \mathrm{m}^{3}$ on 31 March 2020 that accounts for nearly $83 \%$ decline in the $\mathrm{NH}_{3}$ concentration. The two possible sources of ammonia in Jahangir Puri region may be due to the open roadside urinals lined up in front of JJ Colony, which is just next to the National Highway 44 . The secondary reason for this spike in concentration of ammonia may be the waste disposal dump-yard like a hill located just $500 \mathrm{~m}$ ahead of the site. Although on the curfew day, the trend witnesses a trough at $36.23 \mu \mathrm{g} / \mathrm{m}^{3}$ on $22 \mathrm{March}$ 2020 due to complete shutdown of public human activities and travel in overcrowded Jahangir Puri region.

By understanding the overall impact of lockdown due to coronavirus pandemic in India specifically focused on Delhi air quality yielded another latent dimension for environmentalists and scientists to plan the future guidelines for resolving environment pollution problem can be summed up from the histograms sketched in Fig. 9. It elaborates how environment parameters have improved remarkably by the measurement of prime four parameters $\left[\mathrm{PM}_{2.5}, \mathrm{PM}_{10}, \mathrm{NO}_{x}\right.$ and $\mathrm{CO}$ ] average data of the four key locations in Delhi. The colosal decrease in all four parameters confirms a boon for COVID-19 infected persons and masses in general due to lockdown clamping in India has helped to improve air quality drastically. Most importantly, the significant decrease in the air pollution markers namely $\mathrm{PM}_{10}, \mathrm{PM}_{2.5}, \mathrm{NH}_{3}, \mathrm{SO}_{2}$, $\mathrm{NO}, \mathrm{NO}_{2}, \mathrm{NO}_{x}$ and $\mathrm{CO}$ are emerging evidences to air pollution being an important environmental factors that may be contributing in disease pathogenesis (Jeong et al. 2019).

\section{NOx CONCENTRATION(ppb)}

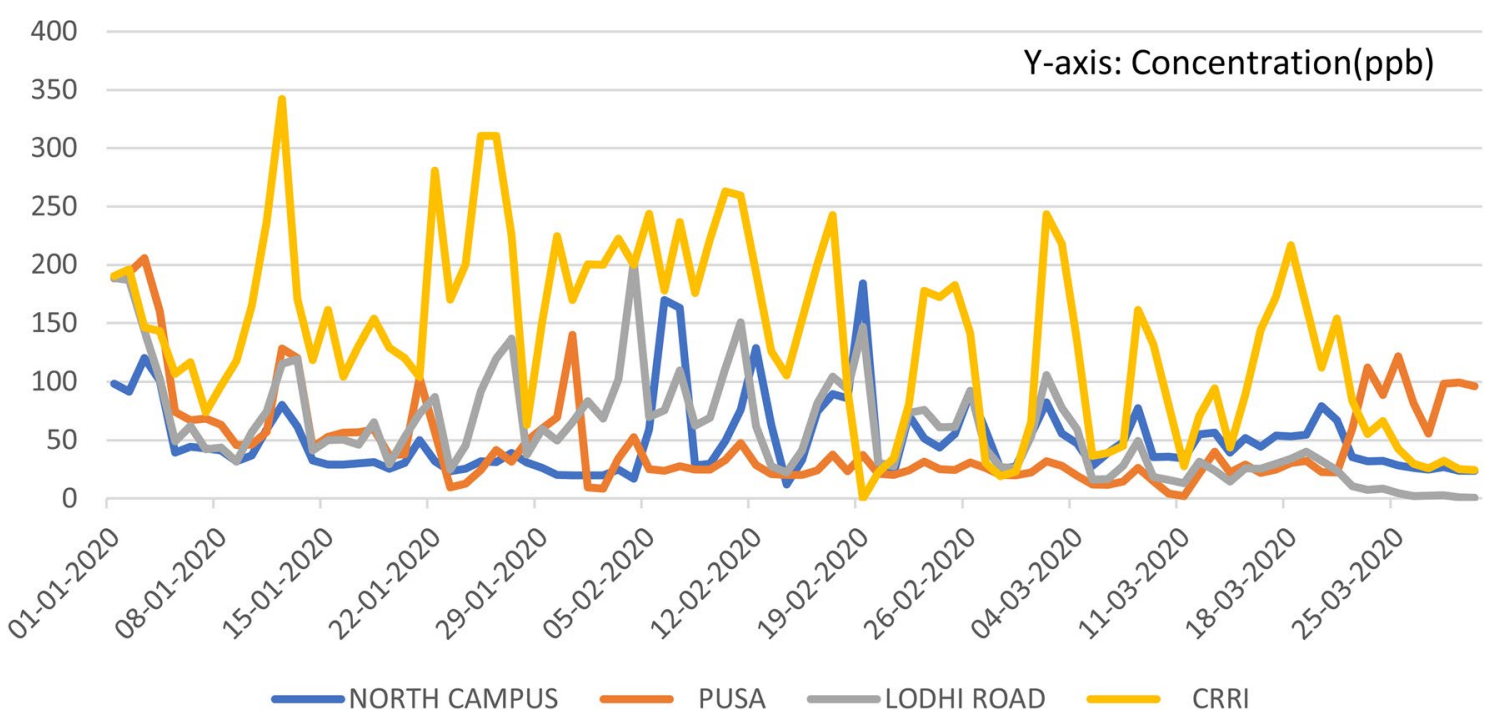

Fig. 7 Decrease trend in $\mathrm{NO}_{x}$ concentration during COVID-19 lockdown period 


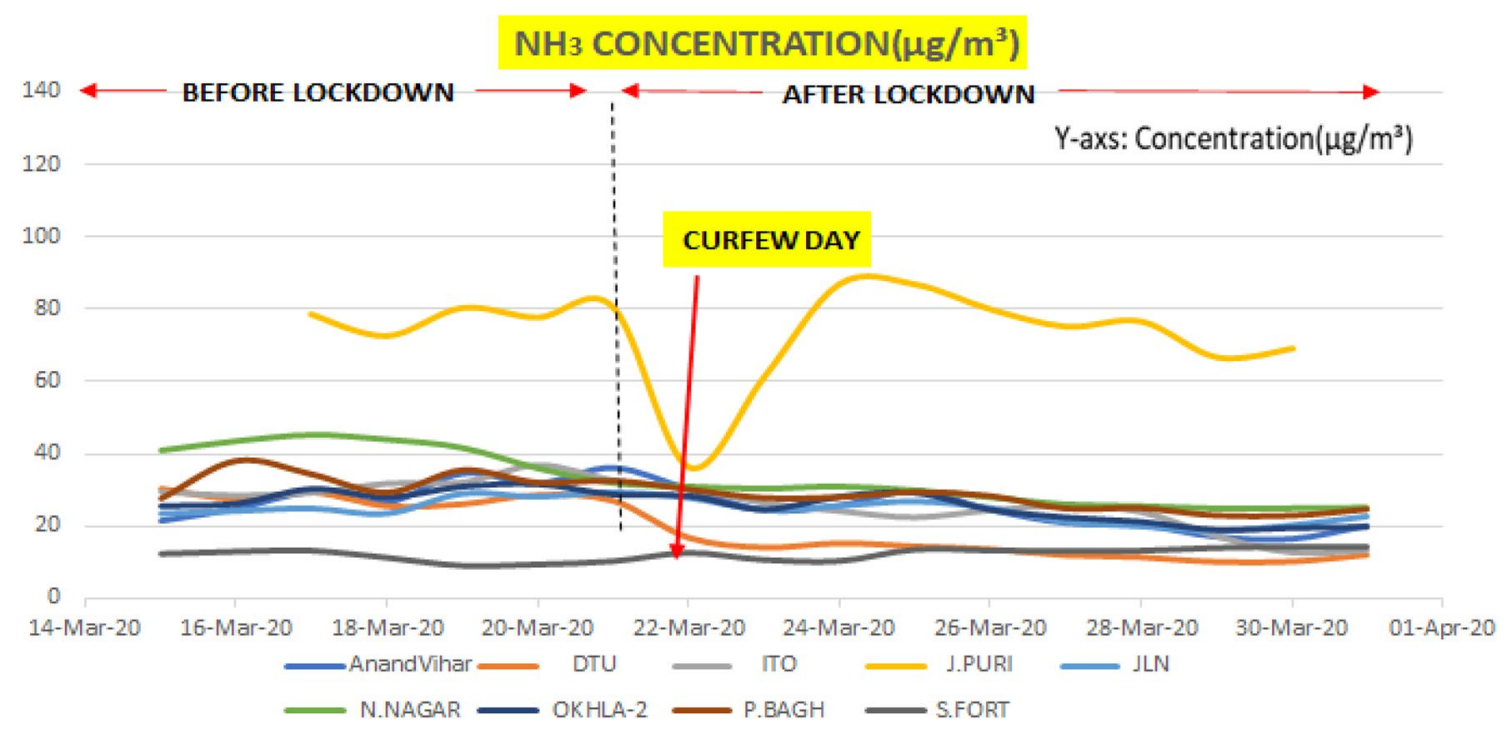

Fig. $8 \mathrm{NH}_{3}$ concentration during pre-lockdown and post-lockdown period in Delhi

During the COVID-19 lockdown period, the concentration surface $\mathrm{O}_{3}$ is also reduced over Delhi region may be due to narrowing down of its precursor gases, i.e. $\mathrm{NO}, \mathrm{NO}_{2}, \mathrm{CO}$ and non-methane hydrocarbon, etc. (data not reported).

\section{Conclusions}

The analysis of early data in this study indicates that government enacted emergency measures to shut the movement of human activity, commercial and industrial pursuits and transportation means that have effectively and significantly reduced the ambient air pollution across Delhi region. Although the COVID-19 pandemic poses a potential risk for health and wellbeing of populations globally, especially those living in high-density urban areas; the impacts of air pollution are equally consequential. On March 24, 2020 India implemented lockdown in the country for 21 days to prevent the community spread of virus among people. The experimental data pattern has depicted explicitly the significant reduction in the $\mathrm{PM}$ and trace gases $\left(\mathrm{PM}_{10}, \mathrm{PM}_{2.5}, \mathrm{NH}_{3}\right.$, $\mathrm{SO}_{2}, \mathrm{NO}, \mathrm{NO}_{2}, \mathrm{NO}_{x}$ and $\mathrm{CO}$ ) concentrations across the megacity Delhi. Ultimately, the air quality analysis in the present study suggests that lockdown has helped us in circumventing the corona virus community spread besides a boon for air quality improvement in unimaginable limits that compels environmentalists to resolve and re-direct the environmental pollution issues in new dimensions. Therefore, a cleaner environment would prove to be an effective measure to halt and reduce the transmission of viral infections. Although mandating changes to economic or transportation activity or investing in clean technology would better protect human health from the effects of air pollution and thereby leading to a reduced community transmission of viral infections too. Delhi has noticed recently a memorable pristine blue sky during COVID-19 outbreak lockdown period. 
Fig. 9 Maxima-minima in a $\mathrm{PM}_{2.5}$ concentration, $\mathbf{b} \mathrm{PM}_{10}$ concentration, $\mathbf{c} \mathrm{NO}_{X}$ concentration, $\mathbf{d}$ CO concentration during COVID-19 lockdown period a

PM2.5 During COVID-19 Outbreak

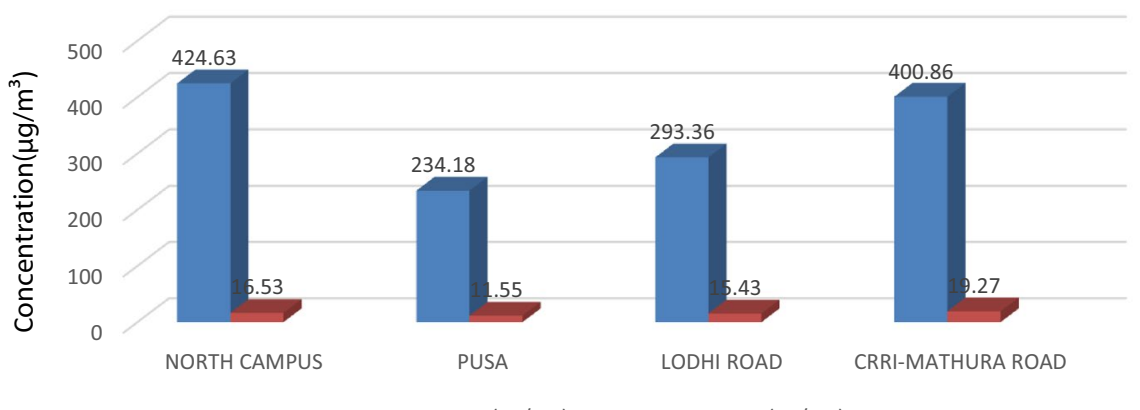

- MAXIMA PM2.5 $(\mu \mathrm{g} / \mathrm{m} 3)$ - MINIMA PM2.5 $(\mu \mathrm{g} / \mathrm{m3})$

b

PM10 During COVID-19 Outbreak

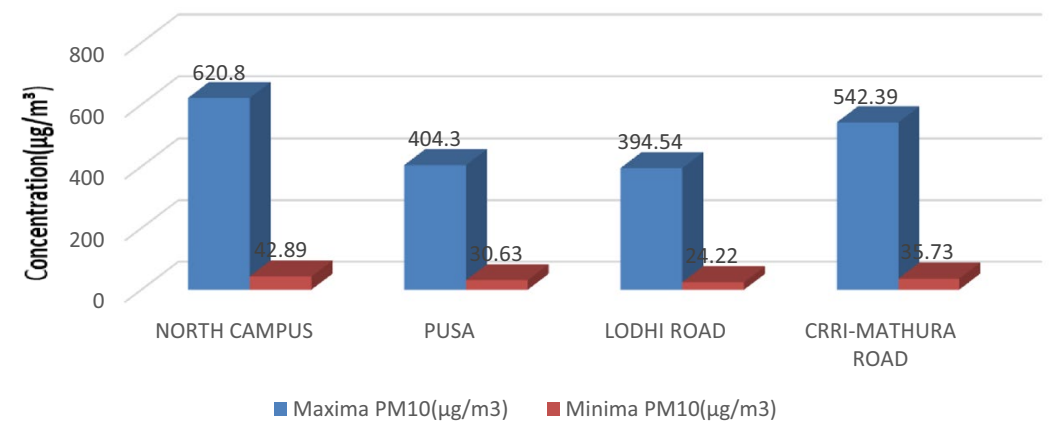

C

NOX During COVID-19 Outbreak
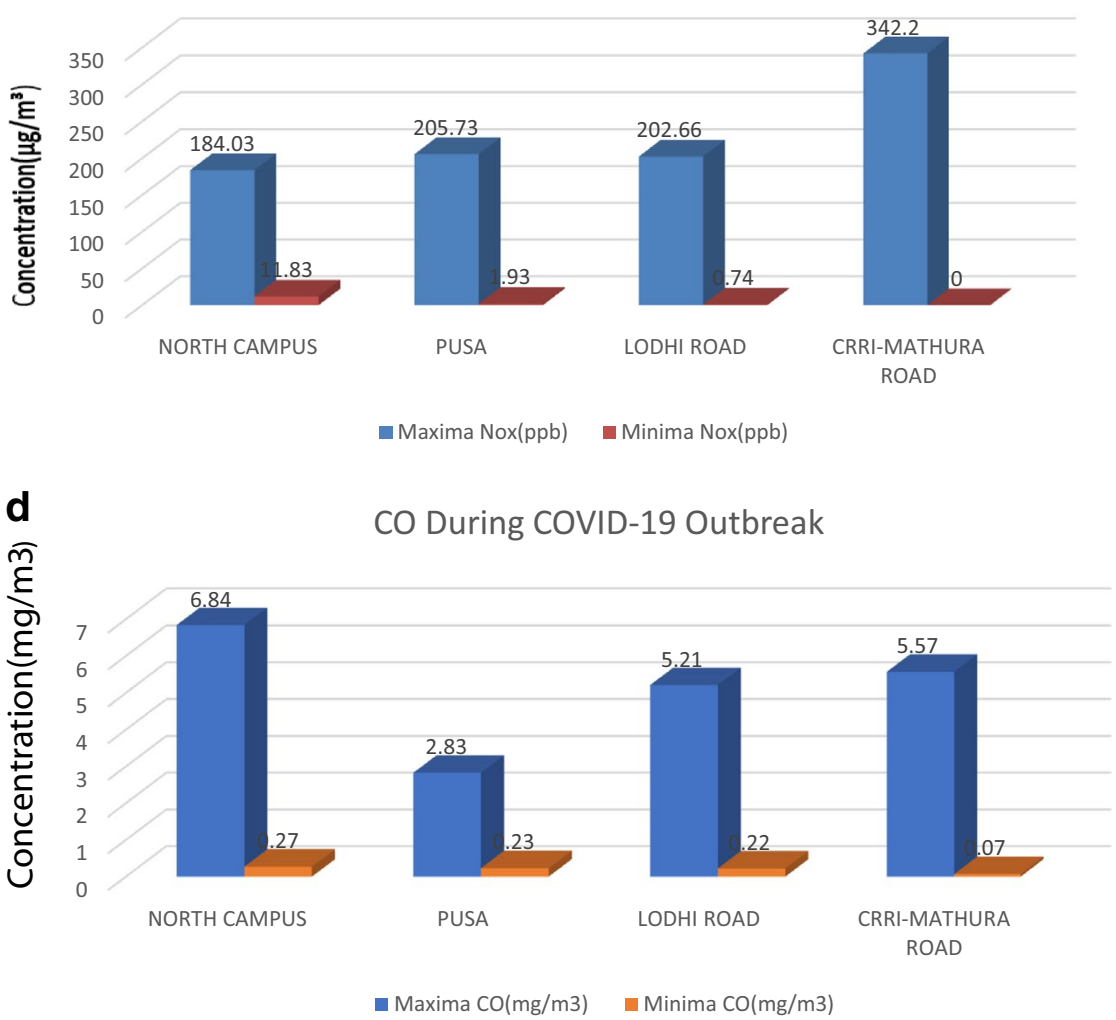
Acknowledgements The authors are thankful to the Director, CSIRNational Physical Laboratory, New Delhi and Head, Environmental Sciences and Biomedical Metrology Division, CSIR-NPL, New Delhi for their encouragement and support. Authors are grateful to Central Pollution Control Board (CPCB) for providing the data required for this analysis. One of the authors (GK) acknowledges Ministry of Earth Sciences (under DelhiFlux project), New Delhi for providing fellowship during the study period.

\section{References}

Bukhari Q, Jameel Y (2020) Will coronavirus pandemic diminish by summer? SSRN 3556998. https://www.ssrn.com.doi.org/10.2139/ ssrn.3556998

Backer JA, Klinkenberg D, Wallinga J (2020) Incubation period of novel corona virus $(2019 \mathrm{nCoV})$ infections among travellers from Wuhan, China, 20-28 January 2020. Euro Surveill 25(5):2000062

Cesaroni G, Forastiere F, Stafoggia M, Andersen ZJ, Badaloni C, Beelen R, Caracciolo B, de Faire U, Erbel R, Eriksen KT, Fratiglioni L, Galassi C, Hampel R, Heier M, Hennig F, Hilding A, Hoffmann B, Houthuijs D, Jöckel KH, Korek M, Lanki T, Leander K, Magnusson PK, Migliore E, Ostenson CG, Overvad K, Pedersen NL, Penell J, Pershagen G, Pyko A, Raaschou-Nielsen O, Ranzi A, Ricceri F, Sacerdote C, Salomaa V, Swart W, Turunen AW, Vineis P, Weinmayr G, Wolf K, de Hoogh K, Hoek G, Brunekreef B, Peters A (2014) Long term exposure to ambient air pollution and incidence of acute coronary events: prospective cohort study and meta-analysis in 11 European cohorts from the ESCAPE project. BMJ 21:348-412. https://doi.org/10.1136/bmj.f7412

Cadotte MW, Jones HP, Newton EL (2019) Making the applied research that practitioners need and want accessible. Ecolo Sol Evidence. https://doi.org/10.1002/2688-8319.12000

https://www.oie.int/doc/ged/d8191.pdf

COVID-19 Coronavirus pandemic, World meter accessed on 31 March 2020

COVID-19: high pollution, smoking make you more vulnerable to novel coronavirus disease, warn doctors; the weather channel; 18 March 2020

CPCB Air Quality Comparison Report 2020

De Anil K (2019) Environmental chemistry. Air Pollut 10:10
Doctors for Clean Air (DFCA)-The Weather Channel/The Times of India/18March2020 stated: Marc Cadotte : Early evidence that COVID-19 government policies reduce urban air pollution, March 30,2020

Greenberg N, Carel RS, Derazne E, Bibi H, Shpriz M, Tzur D, Portnov BA (2016) Different effects of long-term exposures to $\mathrm{SO}_{2}$ and $\mathrm{NO}_{2}$ air pollutants on asthma severity in young adults. J Toxicol Environ Health Part A 79(342-351):30

Jeong D, Seco R, Gu D, Lee Y, Nault BA, Knote CJ, Mcgee T, Sullivan JT, Jimenez JL, Campuzano-Jost P, Blake DR, Sanchez D, Guenther AB, Tanner D, Huey LG, Long R, Anderson BE, Hall SR, Ullmann K, Shin H, Herndon SC, Lee Y, Kim D, Ahn J, Kim S (2019) Integration of airborne and ground observations of nitryl chloride in the Seoul metropolitan area and the implications on regional oxidation capacity during KORUS-AQ 2016. Atmos Chem Phys 19:12779-12795. https://doi.org/10.5194/acp19-12779-2019

Kanawade VP, Srivastava AK, Ram K, Asmi E et al (2019) What caused severe air pollution episode of November 2016 in New Delhi? Atmos Environ 222:117125

Khaniabadi YO, Goudarzi G, Daryanoosh SM, Borgini A, Tittarelli A, De Marco A (2017) Exposure to $\mathrm{PM}_{10}, \mathrm{NO}_{2}$, and $\mathrm{O}_{3}$ and impacts on human health. Environ Sci Pollut Res 24:2781-2789

Nahid M, Ayoung J, Roel V (2019) The mediating effect of immune markers on the association between ambient air pollution and adult-onset asthma. Sci Rep 9:8818

Raaschou NO, Andersen ZJ (2013) Air pollution and lung cancer incidence in 17 European cohorts: prospective analyses from the European Study of Cohorts for Air Pollution Effects (ESCAPE). Lancet Oncol 14(9):813-822

Report on potential impact of Covid-19 on Indian economy, KPMG (Navigating the COVID-19 crisis: avoiding debt defaults and insolvencies as a 'new normal' emerges.)

Tesini BL (2020) Coronaviruses and acute respiratory syndromes (COVID-19, MERS, and SARS). University of Rochester School of Medicine and Dentistry, Rochester

Wang D, Hu B, Hu C et al (2020) Clinical characteristics of 138 hospitalized patients with 2019 novel corona virus infected pneumonia in Wuhan, China. JAMA 323:1061-1069

World Health Organization (2020) Coronavirus disease 2019 (COVID19), Situation report 1-118. https://en.wikipedia.org/wiki/Timel ine_of_the_2019\%E2\%80\%9320_coronavirus_pandemic 